\title{
Deoxyribonucleic Acid Relatedness and Phenotypic Study of the Genus Xenorhabdus
}

\author{
PATRICK A. D. GRIMONT, ${ }^{1 *}$ A. G. STEIGERWALT,${ }^{2}$ NOEL BOEMARE,${ }^{3}$ F. W. HICKMAN-BRENNER, ${ }^{4}$ \\ CHRISTIANE DEVAL, ${ }^{1}$ FRANCINE GRIMONT, ${ }^{1}$ AND DON J. BRENNER ${ }^{2}$ \\ Service des Entérobactéries, Institut National de la Santé et de la Recherche Médicale Unit 199, Institut Pasteur, F-75724 \\ Paris Cedex 15, France ${ }^{1}$; Molecular Biology Laboratory ${ }^{2}$ and Enteric Bacteriology Section, ${ }^{4}$ Centers for Disease \\ Control, Atlanta, Georgia 30333; and Station de Recherches de Pathologie Comparée INRA-CNRS, \\ F-30380 Saint-Christol, France
}

\begin{abstract}
A collection of 30 clones derived from 20 luminous and nonluminous Xenorhabdus strains was studied by using deoxyribonucleic acid (DNA) relatedness and electron microscopy, as well as growth factor requirement, nutritional ability, and other biochemical tests. Nonluminous Xenorhabdus cells each contained a crystal-like structure, whereas the cells of luminous strains each contained an accumulation of amorphous material associated with mesosomes and microtubules of unknown function. Two DNA relatedness groups of nonluminous strains were delineated, one of which corresponded to Xenorhabdus nematophilus, a species associated with the nematode Steinernema feltiae (= Neoplectana carpocapsae). The other group contained yellow-pigmented bacteria associated with Steinernema bibionis and new Steinernema species. No definite phenotypic characteristic (except pigmentation) separated the two DNA relatedness groups of nonluminous Xenorhabdus strains. Four DNA relatedness groups were delineated among the luminous clones studied. These four groups could be separated by biochemical tests. Unfortunately, different clones derived from the same strain belonged to different DNA relatedness groups. This happened with the type strain of Xenorhabdus luminescens.
\end{abstract}

Among the nematodes belonging to the order Rhabditida, two families, the Steinernematidae and the Heterorhabditidae, are composed of organisms whose larvae can penetrate living insects and kill them while developing in their bodies (24). These nematodes contain bacteria in their digestive tracts. The nematode genus Steinernema (now including Neoplectana [29]) is associated with the bacterial species Xenorhabdus nematophilus, whereas the nematode genus Heterorhabditis is associated with the bacterial species Xenorhabdus luminescens $(19,23,25,28)$. Although other bacteria are associated with Steinernema spp. $(22$; N. Boemare, Ph.D. thesis, Université des Sciences, Montpellier, France, 1983), the presence of Xenorhabdus spp. is essential for the mass production of the nematodes used in insect pest control projects (5; Boemare, Ph.D. thesis).

The genus Xenorhabdus Thomas and Poinar 1979 has been assigned to the family Enterobacteriaceae (28).

The purposes of this work were to (i) characterize the species of Xenorhabdus by electron microscopy, (ii) characterize the species of Xenorhabdus by using tests commonly used to describe species in the Enterobacteriaceae, (iii) identify growth factor requirements and determine the nutritional abilities of Xenorhabdus strains, and (iv) delineate the species of Xenorhabdus by deoxyribonucleic acid (DNA)DNA hybridization.

\section{MATERIALS AND METHODS}

Bacterial strains. All strains were purified by picking a single colony on a nutrient agar (Difco Laboratories, Detroit, Mich.) plate. When more than one colonial form were produced by a strain, different colonies were picked and grown separately as different clones. The Xenorhabdus

\footnotetext{
* Corresponding author.
}

strains and clones used in this study are listed in Table 1 . The 81 non-Xenorhabdus reference strains used in the DNA relatedness study included 67 strains listed by Grimont et al. (16) (all strains except Cedecea sp. strain 621-75 and Kluyvera sp. strains 406-78 and 411-78), as well as Edwardsiella tarda 3592-64, Enterobacter agglomerans 2780-70, Enterobacter amnigenus 1319-79 and 1325-79, Enterobacter cloacae 1347-71, Enterobacter gergoviae 7601, Escherichia hermanii 980-76, Escherichia vulneris 2898-73, Ewingella americana 1468-78, Serratia fonticola 4556-71, Serratia marcescens 868-57, Yersinia kristensenii 1476, Yersinia enterocolitica 497-70, and Yersinia pseudotuberculosis P62. These 81 strains represented 73 DNA relatedness groups.

Morphological characterization. Two-day-old cultures in tryptocasein soy broth (Institut Pasteur Production, Marnes-la-Coquette, France) at $30^{\circ} \mathrm{C}$ were examined with an optical microscope after wet mounting and Gram staining. A 2-day-old colony of strain 4 on tryptocasein soy agar (Institut Pasteur Production) was touched with a carboncoated specimen grid, negatively stained with $2 \%(\mathrm{wt} / \mathrm{vol})$ phosphotungstic acid, and examined with a Hitachi model HU 11CS electron microscope. Five-day-old cultures of strains $3,4,14$, and $17 \mathrm{a}$ in tryptocasein soy broth at $28^{\circ} \mathrm{C}$ were fixed with $2.5 \%$ (wt/vol) glutaraldehyde for $2 \mathrm{~h}$ at $6^{\circ} \mathrm{C}$, postfixed in $1 \%(\mathrm{wt} / \mathrm{vol})$ osmium tetroxide for $30 \mathrm{~min}$, embedded in Epon, sectioned, and stained with uranyl acetate and lead citrate.

Characterization as primary or secondary form. A total of 19 clones were characterized as primary or secondary forms by examining colonies grown on nutrient agar (Difco) supplemented with $0.004 \%$ (wt/vol) triphenyltetrazolium chloride and $0.025 \%$ (wt/vol) bromthymol blue (1) or by detecting the production of inhibitory substances against Serratia marcescens 5 and Serratia plymuthica 392, using the method of Akhurst (2).

Biochemical and physiological characterization. All tests 
TABLE 1. Origins of the Xenorhabdus strains studied

\begin{tabular}{|c|c|c|c|c|}
\hline \multirow[b]{2}{*}{ Species } & \multicolumn{3}{|c|}{ Strain designations } & \multirow[b]{2}{*}{ Origin $^{a}$} \\
\hline & $\begin{array}{l}\text { This } \\
\text { paper }\end{array}$ & $\mathrm{CDC}$ & Sender & \\
\hline \multirow[t]{11}{*}{$X$. nematophilus } & la & $9168-81$ & CCEB 786 & $\begin{array}{l}\text { CCEB < ATCC } 19061<\text { G. O. } \\
\text { Poinar; Steinernema feltiae } e^{b}\end{array}$ \\
\hline & $1 b$ & $9012-80$ & ATCC $19061^{\mathrm{T}}$ & $\begin{array}{l}\text { G. M. Thomas; different clone from } \\
\text { the same strain ATCC } 19061^{T}\end{array}$ \\
\hline & 1c & $1184-80$ & ATCC $19061^{T}$ & $\begin{array}{l}\text { ATCC; different clone from the } \\
\text { same strain ATCC } 19061^{\mathrm{T}}\end{array}$ \\
\hline & $2 a$ & $9013-80$ & A11 & $\begin{array}{l}\text { G. M. Thomas; Steinernema sp., } \\
\text { Georgia }\end{array}$ \\
\hline & $2 b$ & & Al1 & Colonial variant from strain $2 \mathrm{a}$ \\
\hline & 3 & & 262 & $\begin{array}{l}\text { N. Boemare; Steinernema feltiae } \\
\text { DD136, France }\end{array}$ \\
\hline & 4 & & 291 & $\begin{array}{l}\text { N. Boemare; Steinernema feltiae } \\
\text { Plougastel, France }\end{array}$ \\
\hline & 5 & $1427-81$ & 301 & $\begin{array}{l}\text { N. Boemare; Steinernema feltiae } \\
\text { Plougastel, France }\end{array}$ \\
\hline & 6 & & 246 & $\begin{array}{l}\text { N. Boemare; Steinernema feltiae } \\
\text { DD136, France }\end{array}$ \\
\hline & 7 & & 288 & $\begin{array}{l}\text { N. Boemare; Steinernema feltiae } \\
\text { Plougastel, France }\end{array}$ \\
\hline & 8 & & 297 & $\begin{array}{l}\text { N. Boemare; Steinernema feltiae } \\
\text { DD136 imported from the United } \\
\text { States }\end{array}$ \\
\hline \multirow[t]{9}{*}{ Xenorhabdus sp. } & 9 & $1426-81$ & 286 & $\begin{array}{l}\text { N. Boemare; Steinernema species } 1 \text {, } \\
\text { Brittany, France }\end{array}$ \\
\hline & 10 & $2411-80$ & $\mathbf{R}$ & $\begin{array}{l}\text { G. M. Thomas; Steinernema sp., } \\
\text { Massachusetts }\end{array}$ \\
\hline & $11 \mathrm{a}$ & $9015-80$ & $\mathrm{X}-\mathrm{II}$ & $\begin{array}{l}\text { G. M. Thomas; unidentified nema- } \\
\text { tode, Poland }\end{array}$ \\
\hline & $11 b$ & & X-II & Colonial variant of clone $11 \mathrm{a}$ \\
\hline & 12 & $1425-81$ & 276 & $\begin{array}{l}\text { N. Boemare; Steinernema species } 2 \text {, } \\
\text { Aquitaine, France }\end{array}$ \\
\hline & 13 & & 269 & $\begin{array}{l}\text { N. Boemare; Steinernema sp. close } \\
\text { to Steinernema bibionis, Norman- } \\
\text { dy, France }\end{array}$ \\
\hline & 14 & & 278 & $\begin{array}{l}\text { N. Boemare; Steinernema bibionis, } \\
\text { Lorraine, France }\end{array}$ \\
\hline & 15 & & 293 & $\begin{array}{l}\text { N. Boemare; Steinernema species } 2 \text {, } \\
\text { Picardy, France }\end{array}$ \\
\hline & 16 & $9014-80$ & $\mathrm{DN}$ & $\begin{array}{l}\text { G. M. Thomas; Steinernema bi- } \\
\text { bionis, Denmark }\end{array}$ \\
\hline \multirow[t]{9}{*}{$X$. luminescens } & $17 \mathrm{a}$ & $9167-81$ & $\mathrm{Hb}$ & $\begin{array}{l}\text { G. M. Thomas; Heterorhabditis } \\
\text { bacteriophora, Australia }\end{array}$ \\
\hline & $17 \mathrm{~b}$ & $9016-80$ & $\mathrm{Hb}$ & Same origin as clone $17 \mathrm{a}$ \\
\hline & $17 \mathrm{c}$ & & $\mathrm{Hb}$ & Colonial variant of clone $17 \mathrm{a}$ \\
\hline & $17 d$ & $1185-80$ & ATCC 29999 & $\begin{array}{l}\text { ATCC }<\text { G. M. Thomas } \mathrm{Hb} \text {; differ- } \\
\text { ent clone from strain } \mathrm{Hb}\end{array}$ \\
\hline & $18 \mathrm{a}$ & $2294-80$ & $\mathrm{Hb} \mathrm{B}$ & $\begin{array}{l}\text { G. M. Thomas; Heterorhabditis, } \\
\text { Georgia }\end{array}$ \\
\hline & $18 \mathrm{~b}$ & & $\mathrm{Hb} \mathrm{B}$ & Colonial variant of clone $18 \mathrm{a}$ \\
\hline & 19 & $2295-80$ & $\mathrm{Hm}$ & $\begin{array}{l}\text { G. M. Thomas; undetermined } \mathrm{He}- \\
\text { terorhabditis, Georgia }\end{array}$ \\
\hline & $20 \mathrm{a}$ & $2296-80$ & NC-19 & $\begin{array}{l}\text { G. M. Thomas, ATCC 29304; He- } \\
\text { terorhabditis heliothidis }\end{array}$ \\
\hline & $\begin{array}{l}20 \mathrm{~b} \\
20 \mathrm{c}\end{array}$ & $1195-80$ & $\begin{array}{l}\text { ATCC } 29304 \\
\text { CCEB } 954\end{array}$ & $\begin{array}{l}\text { ATCC; same source as clone } 20 \mathrm{a} \\
\text { CCEB }<\mathrm{W} . \mathrm{M} \text {. Brooks NC-19; } \\
\text { same source as clone } 20 \mathrm{a}\end{array}$ \\
\hline
\end{tabular}

${ }^{a}$ The name of the sender is given first. The symbol < indicates from whom the sender received the strain. ATCC, American Type Culture Collection, Rockville, Md.; CCEB, Culture Collection of Entomogenous Bacteria, Prague, Czechoslovakia.

${ }^{b}$ A newly proposed nomenclature of insect-parasitic nematodes (union of the genera Steinernema and Neoplectana) has been followed (29).

done at the Institut Pasteur (IP) were incubated at $30^{\circ} \mathrm{C}$ unless otherwise stated. The tests done at the Centers for Disease Control (CDC) were incubated at $25^{\circ} \mathrm{C}$ unless otherwise stated. Growth factor requirements were determined by the method of Clowes and Hayes (10). Carbon source utilization tests (IP) were done with API-CH, API-AO, and API-AA strips (API System, La Balme-Les-Grottes, France). A description and an evaluation of these strips have been published previously (14). The defined medium used with the API-CH, API-AO, and API-AA strips, which was 
provided by API System, was supplemented with nicotinic acid and para-aminobenzoic acid $(1 \mu \mathrm{g} / \mathrm{ml}$ each $)$, as well as serine, tyrosine, and proline $(20 \mu \mathrm{g} / \mathrm{ml}$ each $)$. The strips were examined for growth after 2,4 , and 8 days.

Biochemical reactions were determined at the CDC by using the method of Edwards and Ewing (12), as recently updated (13). The biochemical reactions determined at the IP included the following: the Voges-Proskauer test (27), hydrolysis of gelatin (film methods [21]), production of $\mathrm{H}_{2} \mathrm{~S}$ from glucose-lactose-iron agar (Institut Pasteur Production), growth in peptone-water (10 $\mathrm{g}$ of Bacto-Peptone [Difco], 1 liter of distilled water, $\mathrm{pH} 7$ ) containing $0,2,6$, or $8 \%$ (wt/vol) $\mathrm{NaCl}$, the $\beta$-glucuronidase test $(20)$, and the $\gamma$ glutamyl-transferase test (15). Luminescence was tested by suspending 1 loopful of a Mueller-Hinton agar culture in 10 $\mathrm{ml}$ of distilled water in a scintillation vial and immediately counting in a scintillation counter with a fully opened window setting (4). All other tests done at IP were performed by using procedures described elsewhere (17).

DNA relatedness. The procedure used at $C D C$ included in vivo labeling of DNA with ${ }^{32} \mathrm{P}$ and DNA hybridization by the hydroxyapatite (HA) method $(8,9)$. The temperature at which $50 \%$ of the reassociated DNA is eluted by $0.14 \mathrm{M}$ phosphate buffer $\left[T_{m(e)}\right]$ has been defined previously (8). The value called $\Delta T_{m(e)}$ is the difference between the $T_{m(e)}$ of the homologous reaction and the $T_{m(e)}$ of the heterologous reaction. $\Delta T_{m(e)}$ is an estimate of the divergence between two DNAs (7).

The procedures used at IP included in vitro labeling of DNA with tritium-labeled nucleotides and DNA hybridization by the $S 1$ nuclease-trichloroacetic acid method (18). $\Delta T_{m}$ values were determined by the method of Crosa et al. (11). It has been shown that $\Delta T_{m(e)}$ values determined by the $\mathrm{HA}$ method and $\Delta T_{m}$ values determined by $\mathrm{S} 1$ nuclease methods are similar for a given pair of DNAs (18).

\section{RESULTS}

DNA relatedness. The results obtained when DNAs from nonluminous Xenorhabdus strains or clones 1a, 1c, 9 , and 16 were labeled and tested against unlabeled DNAs from 31 Xenorhabdus strains or clones are shown in Table 2. The results obtained with labeled DNAs from luminous Xenorhabdus strains or clones $17 \mathrm{a}, 17 \mathrm{~b}, 17 \mathrm{~d}, 20 \mathrm{~b}$, and $20 \mathrm{c}$ tested against the same collection of 30 unlabeled DNAs are shown in Table 3. The results obtained with the HA method at CDC agree very well with the results obtained with the S1 nuclease method at IP, although the relative binding ratios yielded by the $S 1$ nuclease method were lower than the values yielded by the HA method, especially when the DNA pairs were from different species.

TABLE 2. Reassociation of DNAs from nonluminous Xenorhabdus species with DNAs from luminous and nonluminous Xenorhabdus species, as determined by the $\mathrm{S} 1$ nuclease method at $60^{\circ} \mathrm{C}$ and the $\mathrm{HA}$ method at $60^{\circ} \mathrm{C}$

\begin{tabular}{|c|c|c|c|c|c|c|}
\hline \multirow{3}{*}{$\begin{array}{c}\text { Source of } \\
\text { unlabeled DNA } \\
\text { (clone) }\end{array}$} & \multicolumn{6}{|c|}{ \% Reassociation with labeled DNA from: } \\
\hline & \multicolumn{2}{|c|}{$X$. nematophilus strain 1a } & \multirow{2}{*}{$\begin{array}{c}X . \text { nematophilus } \\
\text { strain 1c } \\
\text { (HA method) }\end{array}$} & \multicolumn{2}{|c|}{ Xenorhabdus sp. strain 9} & \multirow{2}{*}{$\begin{array}{c}\text { Xenorhabdus sp. } \\
\text { strain } 16 \\
\text { (HA method) }\end{array}$} \\
\hline & $\begin{array}{l}\text { S1 nuclease } \\
\text { method }\end{array}$ & $\begin{array}{c}\text { HA } \\
\text { method }\end{array}$ & & $\begin{array}{l}\text { S1 nuclease } \\
\text { method }\end{array}$ & HA method & \\
\hline \multicolumn{7}{|l|}{ X. nematophilus } \\
\hline 1a & $100(0)^{a}$ & 100 & & 21 & & \\
\hline $1 \mathrm{~b}$ & & 86 & $78(0)$ & & 34 & 35 \\
\hline 1c & $83(0.5)$ & 99 & $100(0)$ & $21(13.0)$ & $51(12.0)$ & 58 \\
\hline $2 \mathrm{a}$ & $91(1.5)$ & 91 & $83(0.5)$ & $21(15.5)$ & $43(10.0)$ & 41 \\
\hline $2 \mathrm{~b}$ & $87(0.5)$ & & & $23(17.0)$ & & \\
\hline 3 & 91 & & & $26(14.5)$ & & \\
\hline 4 & $91(1.0)$ & & & $42(10.0)$ & & \\
\hline 5 & $93(2.5)$ & 97 & & $27(15.0)$ & 41 & \\
\hline 6 & $86(1.0)$ & & & $23(14.5)$ & & \\
\hline 7 & $105(0)$ & & & $22(14.5)$ & & \\
\hline 8 & $102(1.0)$ & & & $27(16.0)$ & & \\
\hline \multicolumn{7}{|l|}{ Xenorhabdus sp. } \\
\hline 9 & $25(16.0)$ & 36 & & $100(0)$ & $100(0)$ & \\
\hline 10 & 29 & & 41 & $74(2.0)$ & $87(1.0)$ & $81(3.0)$ \\
\hline $11 \mathrm{a}$ & 26 & & 51 & $69(1.0)$ & $78(0.5)$ & $80(1.0)$ \\
\hline $11 b$ & 23 & & & $71(1.5)$ & & \\
\hline 12 & 25 & 37 & & $92(2.0)$ & $95(0)$ & \\
\hline 13 & 32 & & & $96(1.5)$ & & \\
\hline 14 & 33 & & & $77(5.0)$ & & \\
\hline 15 & 27 & & 45 & $81(1.0)$ & & \\
\hline 16 & $23(15.0)$ & 33 & & $76(+0.5)$ & $87(0.5)$ & $100(0)$ \\
\hline \multicolumn{7}{|l|}{$X$. luminescens } \\
\hline $17 \mathrm{a}$ & $9(16.0)$ & 22 & & $7(20.0)$ & & \\
\hline $17 b$ & & 22 & $44(6.5)$ & & 28 & 23 \\
\hline $17 \mathrm{c}$ & 8 & & & $9(22.0)$ & & \\
\hline $17 \mathrm{~d}$ & $9(12.5)$ & 37 & & 7 & 25 & 21 \\
\hline $18 \mathrm{a}$ & 10 & 32 & 37 & & 24 & 23 \\
\hline $18 b$ & 11 & & & $11(20.0)$ & & \\
\hline 19 & 10 & 21 & 40 & $9(23.5)$ & 22 & 24 \\
\hline $20 a$ & 10 & 29 & 32 & $9(20.5)$ & 23 & 24 \\
\hline $20 \mathrm{~b}$ & & 17 & $36(9.0)$ & & 24 & 22 \\
\hline $20 \mathrm{c}$ & $12(28.0)$ & & & $10(10.0)$ & & \\
\hline
\end{tabular}

\footnotetext{
${ }^{a}$ The values in parentheses are $\Delta T_{m}$ values (in degrees Celsius).
} 
TABLE 3. Reassociation of DNAs from luminous Xenorhabdus species with DNAs from luminous and nonluminous Xenorhabdus species, as determined by the $\mathrm{S} 1$ nuclease method at $60^{\circ} \mathrm{C}$ and the $\mathrm{HA}$ method at $60^{\circ} \mathrm{C}$

\begin{tabular}{|c|c|c|c|c|c|c|}
\hline \multirow{3}{*}{$\begin{array}{c}\text { Source of } \\
\text { unlabeled DNA } \\
\text { (clone) }\end{array}$} & \multicolumn{6}{|c|}{ \% Reassociation with labeled DNA from $X$. luminescens strain: } \\
\hline & \multicolumn{2}{|c|}{$17 \mathrm{a}$} & \multirow{2}{*}{$\begin{array}{l}\text { 17b (HA } \\
\text { method) }\end{array}$} & \multirow{2}{*}{$\begin{array}{l}17 \mathrm{~d} \text { (HA } \\
\text { method) }\end{array}$} & \multirow{2}{*}{$\begin{array}{l}20 \mathrm{~b} \text { (HA } \\
\text { method) }\end{array}$} & \multirow{2}{*}{$\begin{array}{c}20 \mathrm{c}(\mathrm{S} 1 \\
\text { nuclease } \\
\text { method) }\end{array}$} \\
\hline & $\begin{array}{l}\text { S1 nuclease } \\
\text { method }\end{array}$ & $\begin{array}{c}\text { HA } \\
\text { method }\end{array}$ & & & & \\
\hline \multicolumn{7}{|l|}{ X. nematophilus } \\
\hline la & $7(18.5)^{a}$ & 16 & & & & $9(9.0)$ \\
\hline $1 b$ & & 16 & 18 & 22 & 17 & \\
\hline 1c & $6(18.0)$ & 16 & 16 & 27 & 23 & $11(15.5)$ \\
\hline $2 \mathrm{a}$ & $10(18.5)$ & 21 & 20 & 28 & 30 & $14(8.0)$ \\
\hline $2 \mathrm{~b}$ & 9 & & & & & 9 \\
\hline 3 & 10 & & & & & 9 \\
\hline 4 & 9 & & & & & 9 \\
\hline 5 & 10 & 14 & 18 & & & 8 \\
\hline 6 & 8 & & & & & 8 \\
\hline 7 & 9 & & & & & 8 \\
\hline 8 & 11 & & & & & 9 \\
\hline \multicolumn{7}{|l|}{ Xenorhabdus sp. } \\
\hline 9 & $8(18.5)$ & 12 & 13 & & & $10(15.0)$ \\
\hline 10 & 9 & & 22 & $42(8.5)$ & 28 & $9(17.5)$ \\
\hline $11 \mathrm{a}$ & 16 & & 19 & $38(11.5)$ & 25 & 9 \\
\hline $11 \mathrm{~b}$ & 8 & & & & & 9 \\
\hline 12 & 11 & 14 & 15 & & & 7 \\
\hline 13 & 11 & & & & & 10 \\
\hline 14 & 8 & & & & & 7 \\
\hline 15 & 6 & & & & & 9 \\
\hline 16 & $8(13.0)$ & 29 & 32 & $45(9.0)$ & 35 & $9(>20)$ \\
\hline \multicolumn{7}{|l|}{$X$. luminescens } \\
\hline $17 \mathrm{a}$ & $100(0)$ & 100 & & & & $44(12.5)$ \\
\hline $17 \mathrm{~b}$ & & 100 & $100(0)$ & $72(6.5)$ & $60(11.5)$ & \\
\hline $17 \mathrm{c}$ & $100(0.5)$ & 100 & & & & $44(11.5)$ \\
\hline $17 \mathrm{~d}$ & $61(6.5)$ & 70 & 57 & $100(0)$ & $65(10.0)$ & $40(10.5)$ \\
\hline $18 \mathrm{a}$ & $103(0.0)$ & & $99(1.0)$ & $71(7.0)$ & $58(9.0)$ & 39 \\
\hline $18 b$ & $66(6.0)$ & & & & & $44(11.0)$ \\
\hline 19 & $72(8.5)$ & 70 & 53 & $74(7.0)$ & $53(8.0)$ & $45(11.0)$ \\
\hline $20 \mathrm{a}$ & 49 (11.0) & 61 & 48 & $63(11.0)$ & $100(0)$ & $101(0.0)$ \\
\hline $20 \mathrm{~b}$ & & 47 & 51 & $63(10.0)$ & $100(0)$ & \\
\hline $20 \mathrm{c}$ & $48(10.5)$ & & & & & $100(0)$ \\
\hline
\end{tabular}

${ }^{a}$ The values in parentheses are $\Delta T_{m}$ values (in degrees Celsius).

The nonluminous Xenorhabdus strains (strains 1 to 16 ) comprised two DNA relatedness groups (Table 2). The first group contained 11 clones (clones 1a to 8) derived from eight strains. These clones were 83 to $100 \%$ (S1 nuclease method) or 78 to $100 \%$ (HA method) related to the type strain of $X$. nematophilus (strain 1) at $60^{\circ} \mathrm{C}$. The same levels of relatedness were observed at $75^{\circ} \mathrm{C}$ ( $\mathrm{HA}$ method). The $\Delta T_{m}$ values were 0.0 to $2.5^{\circ} \mathrm{C}$. Some variation in relatedness was observed among the three clones derived from strain 1 . However, reassociated DNAs were very stable. The two clones derived from strain 2 (clones $2 \mathrm{a}$ and $2 \mathrm{~b}$ ) gave nearly identical relative binding ratios. This first group corresponded to $X$. nematophilus sensu stricto since it contained the type strain of that species. Of the eight strains of $X$. nematophilus sensu stricto, seven were isolated from Steinernema feltiae and one was from an unidentified Steinernema.

The second group contained nine clones derived from eight strains previously labeled $X$. nematophilus. These clones were 69 to $100 \%$ (S1 nuclease method) or 78 to $100 \%$ (HA method) related to strain 9 at $60^{\circ} \mathrm{C}$ and 80 to $100 \%$ (HA method) related to strain 16 at $60^{\circ} \mathrm{C}$. The same levels of relatedness were observed at $75^{\circ} \mathrm{C}$ (HA method). The $\Delta T_{m}$ values were below $3.0^{\circ} \mathrm{C}$. Clones derived from the same strain behaved alike in DNA hybridization tests. Of the eight strains in this group, two were isolated from Steinernema bibionis, one was isolated from a Steinernema species close to Steinernema bibionis, one was isolated from a new species (species 1), two were isolated from another new species (species 2; new species of Steinernema according to C. Laumond [personal communication to N.B.]), one was isolated from Steinernema sp., and one was isolated from an unidentified nematode. This group constituted a new genomic species since the levels of DNA relatedness with $X$. nematophilus sensu stricto were 21 to $42 \%$ (S1 nuclease method) and 33 to $58 \%$ (HA method) at $60^{\circ} \mathrm{C}$ and 9 to $30 \%$ (HA method) at $75^{\circ} \mathrm{C}$, with $\Delta T_{m}$ values ranging from 10.0 to $16.0^{\circ} \mathrm{C}$. Both groups of nonluminous Xenorhabdus strains (strains 1 to 16 ) were only 6 to $16 \%$ (S1 nuclease method) or 13 to $45 \%$ (HA method) related to luminous Xenorhabdus strains (strains 17 to 20 ) at $60^{\circ} \mathrm{C}$, with $\Delta T_{m}$ values between 6.5 and $28.0^{\circ} \mathrm{C}$. The levels of relatedness between luminous and nonluminous Xenorhabdus strains at $75^{\circ} \mathrm{C}$ were 3 to $27 \%$ (HA method).

The collection of 10 clones derived from four luminous Xenorhabdus strains (labeled $X$. luminescens) was composed of four DNA relatedness groups (Tables 3 and 4). Different clones that supposedly were from the same strain diverged significantly in DNA relatedness. Of the four clones derived from the type strain of $X$. luminescens (strain 17 ), clones $17 \mathrm{a}, 17 \mathrm{~b}$, and $17 \mathrm{c}$ seemed quite similar in DNA 
TABLE 4. Reassociation of DNA from $X$. luminescens strain 19 with DNAs of other selected strains and clones of $X$. luminescens, as determined by the $\mathrm{S} 1$ nuclease method at $60^{\circ} \mathrm{C}$

\begin{tabular}{cc}
\hline Source of unlabeled DNA (clone) & $\begin{array}{c}\text { Relative binding ratio with strain } 19 \\
\text { DNA (\%) }\end{array}$ \\
\hline 19 & $100(0.0)^{a}$ \\
$18 \mathrm{~b}$ & $89(0.5)$ \\
$17 \mathrm{c}$ & $54(7.0)$ \\
$17 \mathrm{~d}$ & $67(7.0)$ \\
$18 \mathrm{a}$ & $59(6.0)$ \\
$20 \mathrm{a}$ & $40(10.5)$ \\
$20 \mathrm{c}$ & $39(9.5)$ \\
\hline
\end{tabular}

${ }^{a}$ The values in parentheses are $\Delta T_{m}$ values (in degrees Celsius).

relatedness. However, clone $17 \mathrm{~d}$ showed only $61 \%$ (S1 nuclease method) or 57 to $72 \%$ (HA method) relatedness to the other clones of strain 17 at $60^{\circ} \mathrm{C}$, with a $\Delta T_{m}$ value of $6.5^{\circ} \mathrm{C}$. The levels of relatedness between clone $17 \mathrm{~d}$ and clones $17 \mathrm{a}$ and $17 \mathrm{~b}$ at $75^{\circ} \mathrm{C}$ were 44 to $51 \%$ (HA method). Of the two clones derived from strain 18 , one (clone 18a) was highly related to clones $17 \mathrm{a}$ and $17 \mathrm{~b}$, whereas the other (clone 18b) was highly related to strain 19 (Table 4). The three clones derived from strain 20 (clones 20a, 20b, and 20c) were highly similar in DNA relatedness studies.

The levels of DNA relatedness between Xenorhabdus and other members of the Enterobacteriaceae (73 DNA relatedness groups studied) ranged from 0 to $14 \%$ (S1 nuclease method) and 2 to $15 \%$ (HA method) at $60^{\circ} \mathrm{C}$

Morphological characterization. The cells of all of the Xenorhabdus strains examined were gram-negative, motile, peritrichous, nonsporeforming, straight rods about 1.5 to 3 by 0.8 to $1.1 \mu \mathrm{m}$. Older cultures ( 3 to 5 days) contained bacilli of varying sizes (up to $8 \mu \mathrm{m}$ long) and spheroplasts 1.4 to $2 \mu \mathrm{m}$ in diameter. Most bacilli and occasional spheroplasts contained refringent inclusions (all strains examined). An electron micrograph of negatively stained strain 4 is shown in Fig. 1. Strain 4 is clearly peritrichous.

Electron microscopic examination of ultrathin sections showed that the cells of nonluminous Xenorhabdus strains 3, 4 , and 14 each contained a crystal appearing as a lozenge measuring 0.4 by $0.2 \mu \mathrm{m}$ and constituted of numerous arrays (Fig. 2). Luminous Xenorhabdus strain 17a contained dense material with a rectangular shape (e.g., 0.6 by 0.7 or 0.5 by $0.2 \mu \mathrm{m}$ ) or crescent shape (up to $0.5 \mu \mathrm{m}$ thick) that was seemingly attached to the cell membrane (Fig. 3). In addition, tubular structures about 120 by $20 \mathrm{~nm}$ arranged in packs of about 5 to 50 tubules were observed in bacilli or spheroplasts.

Characterization as primary or secondary forms. Clones $1 \mathrm{a}, 4,5,7,8,11 \mathrm{~b}, 17 \mathrm{a}$, and 17d, produced blue colonies surrounded by clear zones after 3 to 4 days on nutrient agar containing bromothymol blue and triphenyltetrazolium chloride, whereas clones $3,11 \mathrm{a}, 12,17 \mathrm{c}, 18 \mathrm{a}, 18 \mathrm{~b}, 19,20 \mathrm{a}$, and $20 \mathrm{c}$ produced reddish maroon colonies without clear zones; clones $2 \mathrm{a}$ and 6 were intermediate, producing reddish colonies with faint halos. Clones $3,4,5,8,11 \mathrm{~b}, 18 \mathrm{~b}$, and $20 \mathrm{a}$ produced a substance that inhibited Serratia marcescens 5 and Serratia plymuthica 392, whereas clones 6, 11a, 17a, $17 \mathrm{c}, 17 \mathrm{~d}, 18 \mathrm{a}, 19$, and $20 \mathrm{c}$ failed to produce any inhibitory substance against the two Serratia strains tested. Thus, clones $1 \mathrm{a}, 4,5,7,8$, and $11 \mathrm{~b}$ are primary forms, and clones 6 , $11 \mathrm{a}, 12,17 \mathrm{c}, 18 \mathrm{a}, 19$, and $20 \mathrm{c}$ are secondary forms. Clones $2 \mathrm{a}, 3,17 \mathrm{a}, 17 \mathrm{~d}, 18 \mathrm{~b}$, and $20 \mathrm{a}$ cannot easily be assigned to one form or the other.
Pigment production and luminescence. Colonies of clones 1 to 8 and clone $11 \mathrm{~b}$ were nonpigmented. Colonies of clones 9 to 16 (except clone $11 \mathrm{~b}$ ) and $20 \mathrm{a}$ to $20 \mathrm{c}$ produced a yellow pigment when they were grown on nutrient agar (the pigment of clone 10 was yellowish orange), whereas colonies of clones 17 a to 19 were rusty.

The liquid scintillation counter was very useful for detecting light emission from bacterial suspensions. Suspending a loopful of a culture of $X$. luminescens (clones $17 \mathrm{a}$ to $20 \mathrm{c}$ ) in $10 \mathrm{ml}$ of distilled water yielded about $10^{6} \mathrm{cpm} . X$. nematophilus and Xenorhabdus sp. (clones 1a to 16) and a control culture of Escherichia coli K-12 produced no light (background noise of about $50 \mathrm{cpm}$ ).

Biochemical and physiological characterization. The characteristics of Xenorhabdus strains that were neither 100 nor $0 \%$ positive are shown in Table 5 . The different biochemical patterns observed among luminous Xenorhabdus strains and clones are shown in Table 6.

Different clones derived from the same strain showed marked differences in nutritional and biochemical abilities. Clone la did not produce acid from fructose and utilized acetate, D-alanine, propionate, L-tyrosine, and valerate but not gluconate, whereas clone $1 \mathrm{c}$ showed opposite reactions. Clone $2 \mathrm{~b}$ utilized 2-ketogluconate, 5-ketogluconate, phenylacetate, propionate, and D-ribose, but did not hydrolyze gelatin (film method), whereas clone $2 \mathrm{a}$ utilized none of these substrates but hydrolyzed gelatin (film method). Clone $11 \mathrm{~b}$ produced white colonies and utilized acetate, amygdalin, L-arabinose, D-arabitol, caproate, glycogen, heptanoate, 3hydroxybutyrate, isobutyrate, isovalerate, DL-lactate, methylmannoside, methylxyloside, phenylacetate, propionate, putrescine, D-ribose, D-sorbitol, starch, and valerate, but not L-aspartate or L-serine, whereas clone 11a produced yellow colonies and gave opposite reactions.

A growth factor was considered required when no visible growth occurred in its absence in 8 days. A factor stimulated growth when growth occurred in 1 day in its presence and in more than 1 day in its absence. All strains of $X$. nematophilus sensu stricto tested (strains 1a, 1c, 2a, 3, 4, $5,6,7$, and 8 ) required nicotinic acid for growth. In addition,

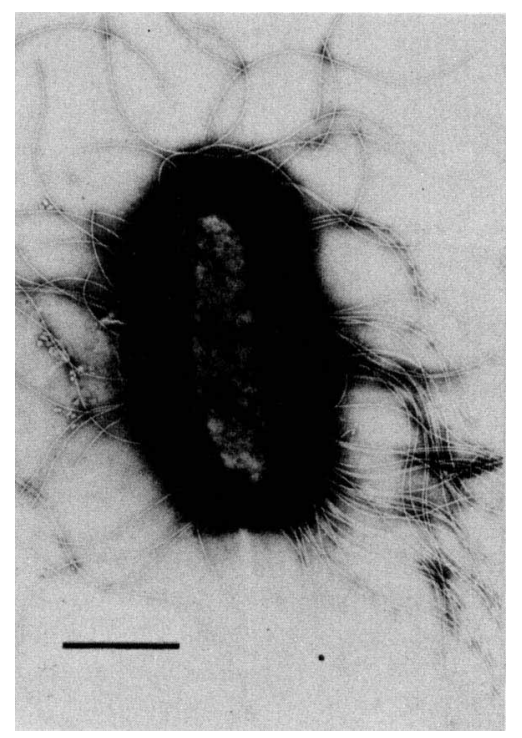

FIG. 1. Electron micrograph of $X$. nematophilus 4. Bar $=1 \mu \mathrm{m}$. 

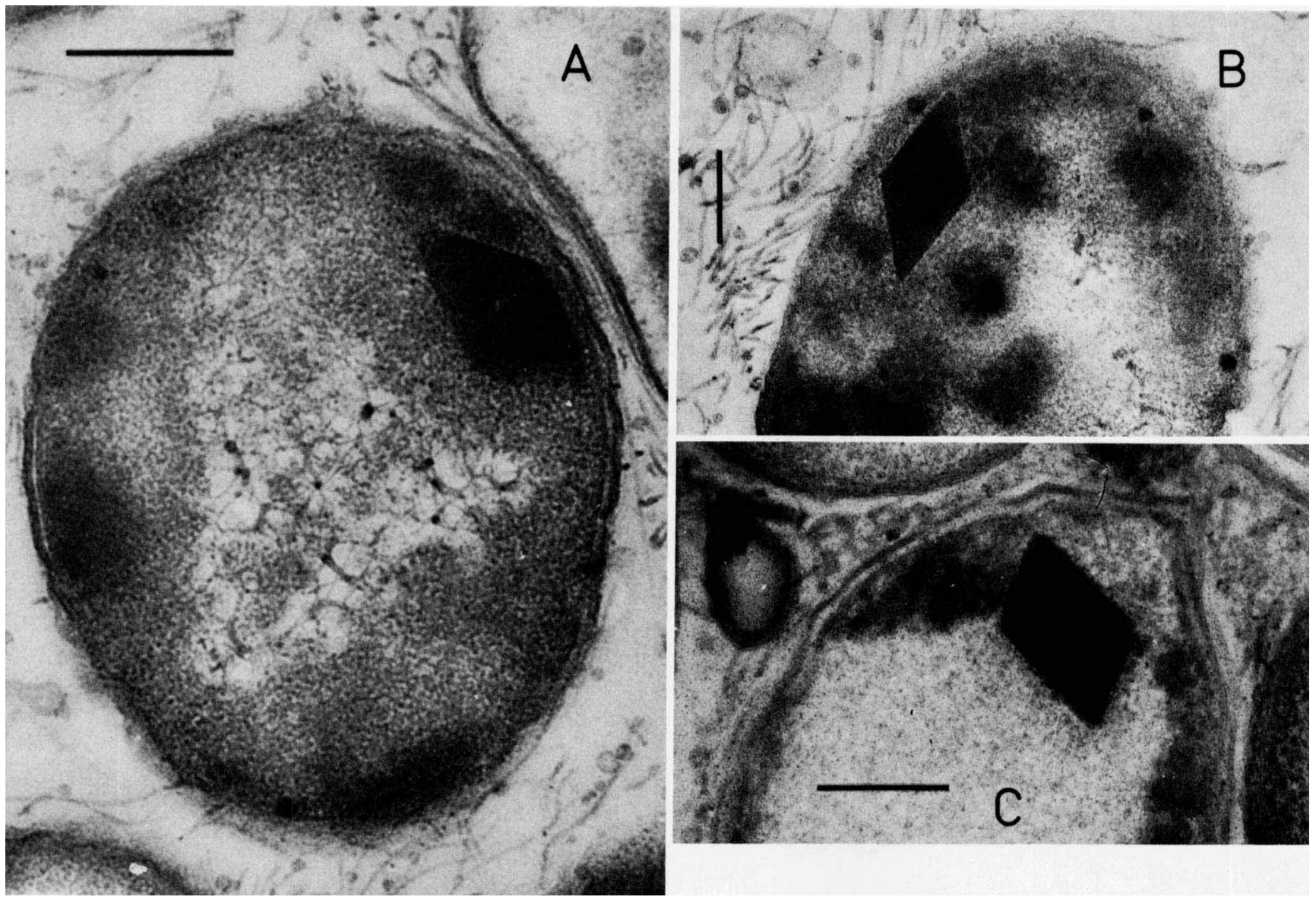

FIG. 2. Ultrathin sections of $X$. nematophilus strains 3 (A) and 4 (B) and Xenorhabdus sp. strain 14 (C), showing crystalline structures. Bars $=200 \mathrm{~nm}$.

strains 1a and 6 required serine and were stimulated by paraaminobenzoic acid. Proline could substitute for nicotinic acid with strain 4.

All strains of Xenorhabdus sp. (the second DNA relatedness group) tested (strains $9,10,11 \mathrm{a}, 11 \mathrm{~b}, 12,13,14,15$, and 16) required nicotinic acid for growth. In addition, strains 9 , 12 , and 14 required tyrosine. Serine and para-aminobenzoic acid could substitute for tyrosine with strain 14 . Strain $11 b$ required serine in addition to nicotinic acid and was stimulated by para-aminobenzoic acid. Strain 15 was stimulated by tyrosine. Strains 12 and 13 grew weakly with the growth factors examined in this study (nicotinate plus tyrosine and nicotinate, respectively), and additional requirements could not be determined. Nicotinic acid was required for growth of $X$. luminescens $18 \mathrm{a}, 18 \mathrm{~b}$, and $20 \mathrm{c}$. In addition, strain $18 \mathrm{a}$ required tyrosine. Proline could substitute for nicotinic acid with strain $18 \mathrm{~b}$, and proline or histidine could substitute for nicotinic acid with strain $20 \mathrm{c}$. The growth of strains $17 \mathrm{a}, 17 \mathrm{c}$, $17 \mathrm{~d}$, and 19 was stimulated by either nicotinic acid or proline. Strain $20 \mathrm{c}$ had no growth factor requirement.

The characteristics that did not vary in the collection of strains or clones tested are described below.

All Xenorhabdus clones tested grew on nutrient agar at $30^{\circ} \mathrm{C}$ in 2 days, producing convex or flat colonies about 1.5 to $3 \mathrm{~mm}$ in diameter. They were facultatively aerobic. All strains grew at 25 and $30^{\circ} \mathrm{C}$ in tryptic soy broth (IP).

All strains except strain 15 produced acid in peptonewater from D-glucose ( 1 to 4 days) and D-mannose (1 to 7 days); strain 15 failed to grow on the peptone-water basal medium (CDC and IP).

All strains of Xenorhabdus used the following compounds as sole carbon and energy sources in 8 days (API medium supplemented with nicotinic acid, para-aminobenzoic acid, serine, tyrosine, and proline): $N$-acetylglucosamine, fumarate, D-glucose, glycerol, D-mannose, and succinate.

None of the Xenorhabdus strains tested produced oxidase (CDC, IP), reduced nitrate to nitrite (although strain 16 gave a faint reaction in one laboratory) (CDC, IP), reduced tetrathionate (IP), or produced $\mathrm{H}_{2} \mathrm{~S}$ (CDC, IP). Malonate broth was not alkaline (CDC, IP), and phenylalanine deaminase (CDC), tryptophan deaminase (IP), lysine decarboxylase (CDC, IP), ornithine decarboxylase (CDC, IP), and arginine decarboxylase ("dihydrolase") (CDC, IP) were not produced. Growth did not occur in tryptic soy broth at 4,40 , and $42^{\circ} \mathrm{C}$ or in peptone-water supplemented with 6 or $8 \%$ $\mathrm{NaCl}$ (IP). Tests for " $\beta$-galactosidase" ( $o$-nitropheny- $\beta$-Dgalactopyranoside test) (CDC, IP), " $\beta$-xylosidase" (IP), and " $\beta$-glucuronidase" (IP) were negative. Starch and chitin were not hydrolyzed (IP). Voges-Proskauer and methyl red tests were negative (CDC, IP). Gas was not produced from D-glucose (CDC, IP). Acid was not produced in peptonewater from adonitol (CDC, IP), L-arabinose (CDC, IP), Darabitol (CDC), cellobiose (CDC, IP), meso-erythritol (CDC), D-galactose (CDC, IP), meso-inositol (CDC, IP), Dmannitol (CDC, IP), D-melibiose (CDC, IP), $\alpha$-methyl-Dglucoside (CDC), mucate (CDC), D-raffinose (CDC, IP), L- 

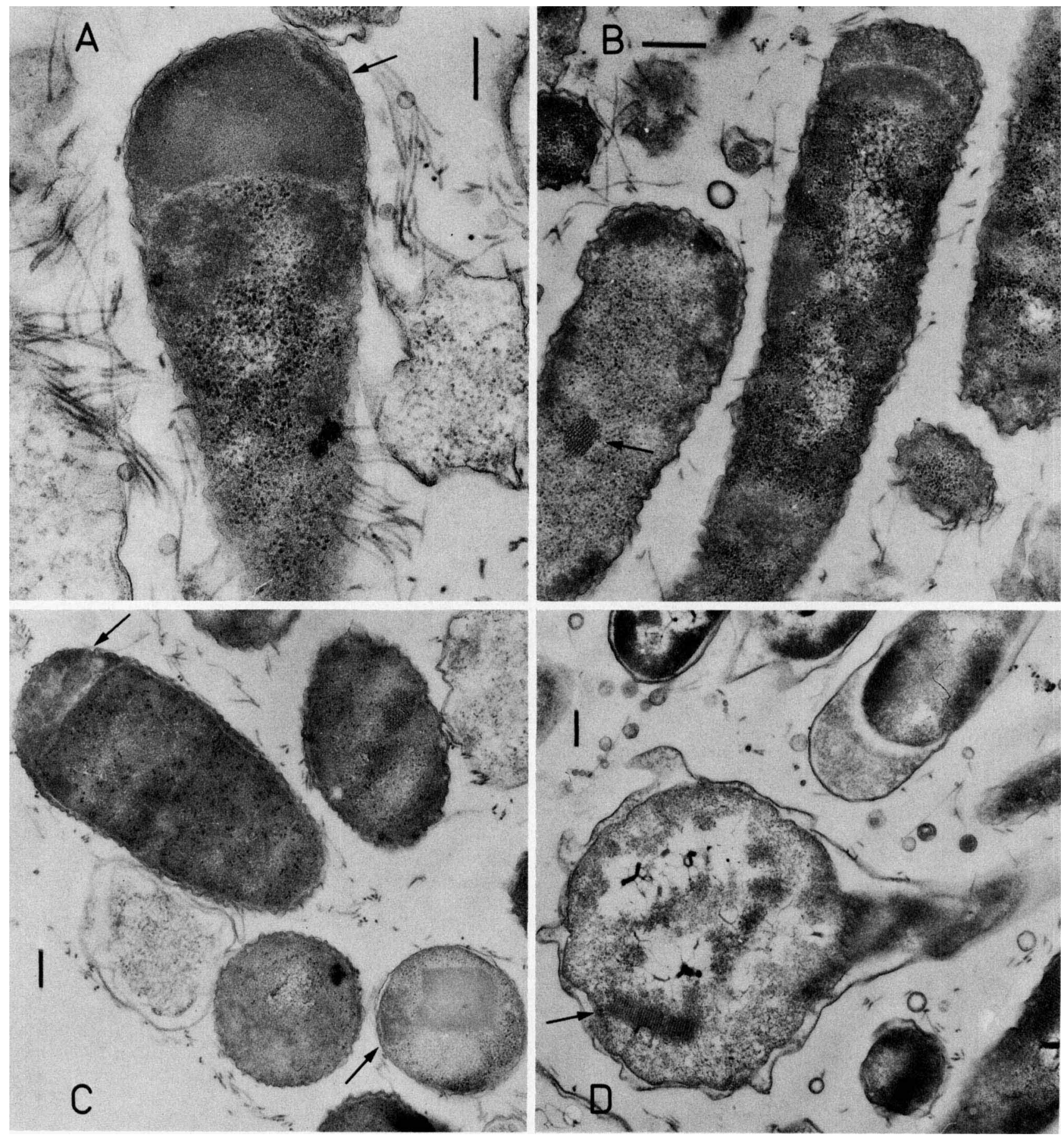

FIG. 3. Ultrathin sections of $X$. luminescens $17 \mathrm{a}$, showing accumulation of amorphous material associated with mesosomes (indicated by arrows in A and C) and microtubules (indicated by arrows in B and D). A spheroplast is shown in (D). Bars $=200 \mathrm{~nm}$.

rhamnose (CDC, IP), D-sorbitol (CDC, IP), L-sorbose (IP), D-sucrose (CDC, IP), or D-xylose (CDC, IP). Trabulsi acetate medium $(C D C)$ was unchanged, and esculin was not hydrolyzed (CDC, IP).

No Xenorhabdus strain could use any of the following substrates as a sole carbon and energy source (API medium supplemented with growth factors): acetamide, trans-aconitate, adipate, adonitol, $\beta$-alanine, 3-aminobenzoate, 4-aminobenzoate, 2 -aminobutyrate, 3 -aminobutyrate, 5 -aminovalerate, $\alpha$-amylamine, anthranilate, D-arabinose, L-arabitol, azelate, benzoate, benzylamine, betaine, butylamine, butyrate, caprylate, citraconate, DL-citrulline, creatine, meso-erythritol, ethanolamine, ethylamine, D-fucose, D-galactose, $\beta$-gentiobiose, glutarate, glycine, glycolate, histamin, 2-hydroxybenzoate, 3-hydroxybenzoate, 4-hydroxybenzoate, inulin, isoleucine, isophthalate, DL-kynurenine, L-leucine, levulinate, L-lysine, maleate, malonate, D-mandelate, L-mandelate, mesaconate, L-methionine, DL-norleucine, DL-norvaline, oxalate, 
TABLE 5. Variable characteristics among Xenorhabdus strains or clones ${ }^{a}$

\begin{tabular}{|c|c|c|c|}
\hline \multirow[b]{2}{*}{ Characteristic $^{b}$} & \multicolumn{3}{|c|}{$\%$ Of positive strains or clones } \\
\hline & $\begin{array}{c}X . \\
\text { nematophilus } \\
\text {. }\end{array}$ & $\begin{array}{l}\text { Xenorhabdus } \\
\text { sp. }\end{array}$ & $X$. luminescens \\
\hline Luminescence (All) $^{c}$ & 0 & 0 & 100 \\
\hline Catalase (All) & 0 & 0 & 100 \\
\hline Indole produced (All) & 0 & 0 & $30-40(10 \mathrm{w})^{d}$ \\
\hline Urea hydrolyzed (All) & 0 & 0 & $0-20(0-30)$ \\
\hline Citrate (Simmons) (All) & $0(27)$ & $0(22-33)$ & $20(50)$ \\
\hline " $\beta$-Xylosidase" (IP) & 0 & 0 & $62(12 w)$ \\
\hline Gelatin hydrolyzed (film method, IP) & $60(30)$ & $44(11)$ & $87(12)$ \\
\hline Gelatin hydrolyzed (tube method, CDC) & $67(33)$ & 100 & $50(50)$ \\
\hline Tween 40 hydrolyzed (IP) & $10(70)$ & (11) & $12(62)$ \\
\hline Tween 40 growth (IP) & 100 & 22 & 100 \\
\hline Tween 60 hydrolyzed (IP) & $(100)$ & $(55)$ & $50(12)$ \\
\hline Tween 80 hydrolyzed (IP) & 10 & $22^{e}$ & 75 \\
\hline Tributyrin hydrolyzed (IP) & $(60)$ & (55) & $25(25)$ \\
\hline DNA hydrolyzed (All) & $18(0-27)$ & $33-44(0-11)$ & $10-20$ \\
\hline \multicolumn{4}{|l|}{ Acid produced from: } \\
\hline Fructose (IP) & $50(40)$ & $11(67)^{e}$ & $12(50)$ \\
\hline Glucose (All) & $45-54(45-54)$ & $67(33)^{e}$ & $50-70(30-50)$ \\
\hline Glycerol (All) & (9) & $0^{e}$ & $(0-10)$ \\
\hline Maltose (All) & $(64)^{f}$ & $(44-55)^{e}$ & $(70-80)$ \\
\hline Mannose (All) & $45(55)$ & $33(55)^{e}$ & $30-60(40-70)$ \\
\hline Salicin (All) & 0 & $0^{e}$ & (20) \\
\hline Trehalose (All) & $(64-73)$ & $(0-11)^{e}$ & $(40)^{f}$ \\
\hline $\begin{array}{l}\text { Growth on tryptic soy agar at } 36^{\circ} \mathrm{C} \\
\text { (CDC) }\end{array}$ & 100 & 0 & $\mathrm{NT}^{g}$ \\
\hline \multicolumn{4}{|l|}{ Growth in tryptic soy broth at: } \\
\hline $15^{\circ} \mathrm{C}(\mathrm{IP})^{h}$ & (22) & $12(37)$ & $29(14)$ \\
\hline $37^{\circ} \mathrm{C}(\mathrm{IP})^{h}$ & 67 & 50 & 86 \\
\hline \multicolumn{4}{|l|}{ Growth in peptone-water supplemented with: } \\
\hline $0 \% \mathrm{NaCl}(\mathrm{IP})^{h}$ & 22 & 0 & 29 \\
\hline $2 \% \mathrm{NaCl}(\mathrm{IP})^{h}$ & $67(33)$ & 12 & 100 \\
\hline $4 \% \mathrm{NaCl}(\mathrm{IP})^{h}$ & $11(11)$ & 0 & $14(43)$ \\
\hline Jordan tartrate (CDC) & 0 & $(100 \mathrm{w})$ & (33) \\
\hline Tyrosine hydrolyzed (CDC) & (33) & $(33 w)$ & $83(17)$ \\
\hline \multicolumn{4}{|l|}{$\begin{array}{l}\text { Utilization of compounds as sole carbon } \\
\text { and energy sources (IP) }\end{array}$} \\
\hline Acetate & 80 & 11 & 100 \\
\hline D-Alanine & 60 & 0 & 62 \\
\hline L-Alanine & 100 & 89 & 100 \\
\hline Amygdalin & 0 & 22 & 0 \\
\hline L-Arabinose & 0 & 22 & 0 \\
\hline L-Aspartate & 100 & 67 & 87 \\
\hline Caprate & 0 & 0 & 25 \\
\hline D-Cellobiose & 0 & 33 & 12 \\
\hline Citrate & 30 & 55 & 12 \\
\hline D-Fructose & 100 & 89 & 100 \\
\hline L-Fucose & 0 & 0 & 25 \\
\hline Gluconate & 20 & 100 & 100 \\
\hline D-Glucosamine & 80 & 89 & 100 \\
\hline L-Glutamate & 100 & 78 & 100 \\
\hline DL-Glycerate & 100 & 89 & 100 \\
\hline L-Histidine & 100 & 67 & 37 \\
\hline myo-Inositol & 100 & 33 & 100 \\
\hline 2-Ketogluconate & 40 & 22 & 0 \\
\hline 5-Ketogluconate & 30 & 0 & 0 \\
\hline DL-Lactate & 100 & 67 & 0 \\
\hline D-Lyxose & 10 & 33 & 0 \\
\hline D-Malate & 0 & 0 & 25 \\
\hline L-Malate & 90 & 100 & 100 \\
\hline Maltose & 100 & 78 & 100 \\
\hline Mannitol & 0 & 33 & 50 \\
\hline D-Melezitose & 0 & 33 & 0 \\
\hline D-Melibiose & 0 & 33 & 0 \\
\hline$\alpha$-Methyl- $D$-glucoside & 0 & 33 & 0 \\
\hline Phenylacetate & 20 & 11 & 0 \\
\hline L-Proline & 100 & 89 & 100 \\
\hline Propionate & 40 & 11 & 50 \\
\hline
\end{tabular}


TABLE 5-Continued

\begin{tabular}{|c|c|c|c|}
\hline \multirow[b]{2}{*}{ Characteristic $^{b}$} & \multicolumn{3}{|c|}{$\%$ Of positive strains or clones } \\
\hline & $\begin{array}{c}X \\
\text { nematophilus }\end{array}$ & $\begin{array}{c}\text { Xenorhabdus } \\
\text { sp. }\end{array}$ & $X$. luminescens \\
\hline Putrescine & 30 & 44 & 0 \\
\hline Pyruvate & 100 & 89 & 100 \\
\hline D-Raffinose & 0 & 33 & 0 \\
\hline L-Rhamnose & 0 & 22 & 0 \\
\hline D-Ribose & 10 & 67 & 100 \\
\hline Salicin & 0 & 33 & 25 \\
\hline L-Serine & 90 & 78 & 100 \\
\hline Starch & 0 & 22 & 50 \\
\hline Sucrose & 0 & 44 & 0 \\
\hline L-Threonine & 90 & 11 & 50 \\
\hline Trehalose & 100 & 87 & 100 \\
\hline D-Turanose & 0 & 22 & 0 \\
\hline L-Tyrosine & 60 & 33 & 100 \\
\hline Valerate & 80 & 22 & 25 \\
\hline D-Xylose & 0 & 33 & 0 \\
\hline
\end{tabular}

${ }^{a}$ The values on the table are percentages of positive strains or clones. The percentages of delayed positive (excluding promptly positive) strains or clones are indicated in parentheses, and the percentages of weak reactions are indicated by $w$. Tests for which only one strain was positive are not listed on the table. These tests are acid production from glycerol (strain 5) and utilization of 4-aminobutyrate (strain 10), D-arabitol (strain 11b), arbutin (strain 14), caproate, glycogen, heptanoate, 3-hydroxybutyrate, isobutyrate, and isovalerate (strain 11b), lactose (strain 14), and methyl-mannoside, methyl-xyloside, and D-sorbitol (strain 11b).

${ }^{b}$ The results of the carbon source utilization tests were determined after 10 days; the results of tests for indole production, gelatin hydrolysis (film method), acid production from carbohydrates, and growth at different temperatures and $\mathrm{NaCl}$ concentrations were determined after 1 and 7 days; the results of tests for urea hydrolysis, Simmons citrate, gelatin hydrolysis (tube method), Tween hydrolysis, tributyrin hydrolysis, DNA hydrolysis, and tyrosine hydrolysis were determined after 2 and 7 days; Jordan tartrate and " $\beta$-xylosidase" tests were examined after 2 and 1 days, respectively.

Unless indicated otherwise, the numbers of strains or clones tested at the CDC, IP, and both laboratories (All) were as follows: X. nematophilus, 3 , 10, and 11 strains, respectively; Xenorhabdus sp., 3, 9, and 9 strains, respectively; X. luminescens, 6, 8, and 10 strains, respectively. For each characteristic we indicate where the test was performed so that the number of strains or clones tested for each species and each characteristic can be deduced.

${ }^{d}$ Discrepancies between laboratories are indicated by two values. This is an underestimate of variability since the number of clones that were studied in duplicate was the number of clones studied at CDC plus the number of clones studied at IP minus the number of clones studied at both laboratories.

One strain failed to grow.

$f$ Two compensated discrepancies.

$\&$ NT, Not tested.

${ }^{h}$ Nine strains of $X$. nematophilus, eight strains of Xenorhabdus sp., and seven strains of $X$. luminescens were studied.

2-oxoglutarate, pelargonate, phthalate, pimelate, sarcosine, sebacate, sorbose, spermine, suberate, D-tagatose, D-tartrate, $\mathrm{L}$-tartrate, meso-tartrate, terephthalate, trigonelline, tryptamine, D-tryptophan, L-tryptophan, L-valine, xylitol, and L-xylose (IP).

\section{DISCUSSION}

Genus Xenorhabdus. It is not clear whether the luminous and nonluminous species should be maintained in the same genus. DNA relatedness data alone cannot be used to define a genus. Electron micrographs showed major differences between luminous and nonluminous species. No crystal-like structures were seen in the cells of luminous strains, and amorphous structures associated with mesosomes or packs of microtubules have not been observed in nonluminous species. Accumulation of amorphous material in luminous species was misinterpreted as crystals in a preliminary work (6). In fact, this amorphous material can take different shapes, but crystalline arrays have never been observed (as opposed to what can be seen on $X$. nematophilus crystals [6]). In contrast to $X$. nematophilus crystals, the amorphous material in $X$. luminescens is always associated with mesosomes (Fig. 3). Pigment production, luminescence, and catalase production distinguish luminous Xenorhabdus species from nonluminous Xenorhabdus species.

The genus Xenorhabdus can be clearly differentiated from all other genera in the Enterobacteriaceae by DNA-DNA hybridization. Furthermore, the cells of Xenorhabdus spp. contain structural elements that have never been reported in any other member of the Enterobacteriaceae or any other gram-negative bacterium. The question of inclusion of Xenorhabdus in the Enterobacteriaceae could be raised. Xenorhabdus spp. have all of the characteristics defining the Enterobacteriaceae (12) except the ability to reduce nitrate to nitrite. In this property, and in general physiological properties, the genus Xenorhabdus is very similar to Erwinia

TABLE 6. Different biochemical patterns among luminous Xenorhabdus strains and clones

\begin{tabular}{|c|c|c|c|c|}
\hline \multirow[b]{2}{*}{ Characteristic } & \multicolumn{4}{|c|}{ Reactions of clones: ${ }^{a}$} \\
\hline & $\begin{array}{c}17 \mathrm{a}, 17 \mathrm{~b} \\
17 \mathrm{c} \text {, and } \\
18 \mathrm{a}\end{array}$ & $17 \mathrm{~d}$ & $\begin{array}{c}18 \mathrm{~b} \text { and } \\
19\end{array}$ & $\begin{array}{c}20 \mathrm{a}, \\
20 \mathrm{~b} \text {, and } \\
20 \mathrm{c}\end{array}$ \\
\hline Pigment & $\mathbf{R}$ & $\mathrm{R}$ & $\mathbf{R}$ & $\mathrm{Y}$ \\
\hline Citrate (Simmons) & + & + & + & - \\
\hline " $\beta$-Xylosidase" & + & + & + & - \\
\hline Tween 40 or 60 hydrolyzed & - or $(+)$ & - & + & + \\
\hline Tween 80 hydrolyzed & + & - & + & + or - \\
\hline Deoxyribonuclease & - & - & + & - \\
\hline Tributyrin hydrolyzed & - & - & $(w)$ & + \\
\hline \multicolumn{5}{|l|}{ Utilization of: } \\
\hline D-Alanine & + & - & + & - \\
\hline Citrate & - & + & - & - \\
\hline L-Fucose & - & - & + & - \\
\hline L-Histidine & - & + & + & - \\
\hline Salicin & - & - & - & + \\
\hline
\end{tabular}

${ }^{a} \mathbf{R}$, Rusty, $\mathrm{Y}$, yellow; + , positive for all clones tested; - or $(+)$, negative or delayed positive reaction; + or - , some clones positive and some clones negative; (w), delayed and weak reaction for all clones tested; - , negative for all clones tested. 
amylovora. The enterobacterial common antigen has been recently demonstrated in Xenorhabdus species (26).

Nonluminous Xenorhabdus species. All of the symbionts recovered from Steinernema feltiae (synonyms, Neoplectana carpocapsae, Neoplectana feltiae) formed a well-defined DNA relatedness group corresponding to $X$. nematophilus. At least three nematode species (Steinernema bibionis and two new Steinernema species) were associated with the second DNA relatedness group, Xenorhabdus sp.

Different clones derived from the same strain were reasonably similar in DNA relatedness tests. However, phenotypic differences between clones (e.g., clones 11a and 11b) were marked and unexplained. After publication of a paper by Akhurst (1) describing morphological and functional dimorphism in Xenorhabdus spp., we tried to identify the form (primary or secondary) of some clones. It seems that phenotypically different clones (e.g., clones $11 \mathrm{a}$ and $11 \mathrm{~b}$ ) derived from the same strain correspond to different forms. However, we could not match absorption of bromthymol blue (on nutrient agar containing bromthymol blue and triphenyltetrazolium chloride) and production of inhibitory substances (these characterize the primary form) with any specific growth factor requirement, carbon source utilization pattern, or other biochemical test.

The phenotypic instability of nonluminous Xenorhabdus strains prevented the identification of any differential test (except yellow pigmentation) to separate the two genomic (DNA relatedness) groups. Recently, Akhurst (3) subdivided $X$. nematophilus into three subspecies, $X$. nematophilus subsp. nematophilus, $X$. nematophilus subsp. bovieni, and $X$. nematophilus subsp. poinarii. $X$. nematophilus subsp. nematophilus corresponds unambiguously to our $X$. nematophilus genomic group. $X$. nematophilus subsp. bovieni contains yellow-pigmented strains recovered from Steinernema bibionis, which hydrolyze Tween 80 but cannot grow at 34 , 36 , or $40^{\circ} \mathrm{C}(3)$. Strains fitting the description of $X$. nematophilus subsp. bovieni are found in our second genomic species, Xenorhabdus sp. However, Xenorhabdus sp. also contains strains that were isolated from nematodes other than Steinernema bibionis and that have characteristics which do not fit the identification scheme of Akhurst (3). A DNA relatedness study in which the strains of Akhurst (3) are used is urgently needed.

Luminous Xenorhabdus species. Some strains labeled $X$. luminescens contained different clones belonging to different DNA relatedness groups. After an exchange of clones between the CDC and IP, four genomic species were clearly delineated. These four species can be separated by using biochemical and nutritional characteristics. The simplest hypothesis to explain the "dimorphism" in $X$. luminescens is that some strains were mixed cultures containing two different luminous Xenorhabdus species. An immediate problem is concerned with the type strain of $X$. luminescens strain ATCC 29999, which does not correspond to strain $\mathrm{Hb}$ received from G. M. Thomas. A well-characterized clone should be redeposited in the American Type Culture Collection to serve as the type strain. Again, we refrained from naming the four luminous species since too few strains were studied.

\section{ACKNOWLEDGMENTS}

Thanks are due to Christian Laumond, Claude Louis, and Roselyne Lesquer for providing nematode specimens, electron microscopy advice, and technical assistance, respectively, to one of us (N.B.). We also thank G. M. Thomas and O. Lysenko for sending strains.

\section{LITERATURE CITED}

1. Akhurst, R. J. 1980. Morphological and functional dimorphism in Xenorhabdus spp., bacteria symbiotically associated with the insect pathogenic nematodes Neoplectana and Heterorhabditis. J. Gen. Microbiol. 121:303-309.

2. Akhurst, R. J. 1982. Antibiotic activity of Xenorhabdus spp., bacteria symbiotically associated with insect pathogenic nematodes of the families Heterorhabditidae and Steinernematidae. J. Gen. Microbiol. 128:3061-3065.

3. Akhurst, R. J. 1983. Taxonomic study of Xenorhabdus, a genus of bacteria symbiotically associated with insect pathogenic nematodes. Int. J. Syst. Bacteriol. 33:38-45.

4. Barak, M., and S. Ulitzur. 1980. Bacterial bioluminescence as an early indication of marine fish spoilage. Eur. J. Appl. Microbiol. Biotechnol. 10:155-165.

5. Bedding, R. A. 1981. Low cost in vitro mass production of Neoplectana and Heterorhabditis species (Nematoda) for field control of insect pests. Nematologica 27:109-114.

6. Boemare, N., C. Louis, and G. Kuhl. 1983. Etude ultrastructurale des cristaux chez Xenorhabdus spp., bactéries inféodées aux nématodes entomophages Steinernematidae et Heterorhabditidae. C. R. Soc. Biol. 177:107-115.

7. Bonner, T. I., D. J. Brenner, B. R. Neufeld, and R. J. Britten. 1973. Reduction in the rate of DNA reassociation by sequence divergence. J. Mol. Biol. 81:123-135.

8. Brenner, D. J., G. R. Fanning, A. V. Rake, and K. E. Johnson. 1969. Batch procedure for thermal elution of DNA from hydroxyapatite. Anal. Biochem. 28:447-459.

9. Brenner, D. J., A. C. McWhorter, J. K. Leete-Knudson, and A. G. Steigerwalt. 1982. Escherichia vulneris: a new species of Enterobacteriaceae associated with human wounds. J. Clin. Microbiol. 15:1133-1140.

10. Clowes, R. C., and W. Hayes. 1968. Experiments in microbial genetics. Blackwell Scientific Publications, Oxford

11. Crosa, J. H., D. J. Brenner, and S. Falkow. 1973. Use of singlestrand-specific nuclease for analysis of bacterial and plasmid deoxyribonucleic acid homo- and heteroduplexes. J. Bacteriol. 115:904-911.

12. Edwards, P. R., and W. H. Ewing. 1972. Identification of Enterobacteriaceae, 3rd ed. Burgess Publishing Co., Minneapolis.

13. Farmer, J. J., III, M. A. Asbury, F. W. Hickman, D. J. Brenner, and The Enterobacteriaceae Study Group. 1980. Enterobacter sakazakii: a new species of Enterobacteriaceae isolated from clinical specimens. Int. J. Syst. Bacteriol. 30:569-584.

14. Gavini, F., D. Izard, H. Leclerc, M. Desmonceaux, and J. P. Gayral. 1980. Carbon source assimilation tests: comparison between a conventional method and a microtechnic (API), in study of Enterobacteriaceae. Zentralbl. Bakteriol. Parasitenkd. Infektionskr. Hyg. Abt. l Orig. Reihe C 1:182-187.

15. Giammanco, G., J. Buissière, M. Toucas, G. Brault, and L. Le Minor. 1980. Intérêt taxonomique de la recherche de la $\gamma$ glutamyltransférase chez les Enterobacteriaceae. Ann. Microbiol. (Paris) 131A:181-187.

16. Grimont, P. A. D., J. J. Farmer III, F. Grimont, M. A. Asbury, D. J. Brenner, and C. Deval. 1983. Ewingella americana gen. nov., sp. nov., a new Enterobacteriaceae isolated from clinical specimens. Ann. Microbiol. (Paris) 134A:39-52.

17. Grimont, P. A. D., F. Grimont, H. L. C. Dulong de Rosnay, and P. H. A. Sneath. 1977. Taxonomy of the genus Serratia. J. Gen. Microbiol. 98:39-66.

18. Grimont, P. A. D., M. Y. Popoff, F. Grimont, C. Coynault, and M. Lemelin. 1980. Reproducibility and correlation study of three deoxyribonucleic acid hybridization procedures. Curr. Microbiol. 4:325-330.

19. Khan, A., and W. M. Brooks. 1977. A chromogenic bioluminescent bacterium associated with the entomophilic nematode Chromonema heliothidis. J. Invertebr. Pathol. 29:253-261.

20. Le Minor, L., J. Buissière, G. Novel, and M. Novel. 1978. Relation entre le sérotype et l'activité $\beta$-glucuronidasique chez les Salmonella. Ann. Microbiol. (Paris) 129B:155-165.

21. Le Minor, L., and M. Piéchaud. 1963. Note technique. Une méthode rapide de recherche de la protéolyse de la gélatine. Ann. Inst. Pasteur (Paris) 105:792-794. 
22. Lysenko, O., and J. Weiser. 1974. Bacteria associated with the nematode Neoplectana carpocapsae and the pathogenicity of this complex for Galleria mellonella larvae. J. Invertebr. Pathol. 24:332-336.

23. Poinar, G. O., and G. M. Thomas. 1965. A new bacterium, Achromobacter nematophilus sp. nov. (Achromobacteriaceae: Eubacteriales), associated with a nematode. Int. Bull. Bacteriol. Nomencl. Taxon. 15:249-252.

24. Poinar, G. O., and G. M. Thomas. 1966. Significance of Achromobacter nematophilus Poinar and Thomas (Achromobacteriaceae: Eubacteriales) in the development of the nematode DD136 (Neoplectana sp., Steinernematidae). Parasitology 56:385-390.

25. Poinar, G. O., G. M. Thomas, and R. Hess. 1977. Characteristics of the specific bacterium associated with Heterorhabditis bacteriophora (Heterorhabditidae: Rhabditida). Nematologica
23:97-102.

26. Ramia, S., E. Neter, and D. J. Brenner. 1982. Production of enterobacterial common antigen as an aid to classification of newly identified species of the families Enterobacteriaceae and Vibrionaceae. Int. J. Syst. Bacteriol. 32:395-398.

27. Richard, C. 1972. Méthodes rapides pour l'étude des réactions de rouge de méthyle et Voges-Proskauer. Ann. Inst. Pasteur (Paris) 122:979-986.

28. Thomas, G. M., and G. O. Poinar. 1979. Xenorhabdus gen. nov., a genus of entomopathogenic nematophilic bacteria of the family Enterobacteriaceae. Int. J. Syst. Bacteriol. 29:352-360.

29. Wouts, W. M., Z. Mráček, S. Gerdin, and R. A. Bedding. 1982. Neoplectana Steiner, 1929, a junior synonym of Steinernema Travassos, 1927 (Nematoda: Rhabditida). Syst. Parasitol. 4:147-154. 